Boise State University

ScholarWorks

Political Science Faculty Publications and

Presentations

Department of Political Science

8-2019

\title{
Political Parties and Foreign Direct Investment Inflows Among Developing Countries
}

Nisha M. Bellinger

Boise State University, nishabellinger@boisestate.edu

Byunghwan Son

George Mason University

Follow this and additional works at: https://scholarworks.boisestate.edu/polsci_facpubs

Part of the Political Science Commons

\section{Publication Information}

Bellinger, Nisha M. and Son, Byunghwan. (2019). "Political Parties and Foreign Direct Investment Inflows Among Developing Countries". Political Studies, 67(3), 712-731. https://dx.doi.org/10.1177/ 0032321718799015

Bellinger, N.M. \& Son, B. "Political Parties and Foreign Direct Investment Inflows Among Developing Countries", Political Studies, 67(3), pp. 712-731. Copyright @ 2019, The Author(s). Reprinted by permission of SAGE Publications. doi: 10.1177/0032321718799015 
This is an author-produced, peer-reviewed version of this article. The final, definitive version of this document can be found online at Political Studies, published by SAGE. Copyright restrictions may apply. doi: 10.1177/0032321718799015

\title{
Political Parties and Foreign Direct Investment Inflows Among Developing Countries
}

\author{
Nisha M. Bellinger \\ Boise State University
}

\author{
Byunghwan Son \\ George Mason University
}

\begin{abstract}
This paper focuses on the nature of party systems to explain variations in FDI inflows within developing democracies. We hypothesize a positive relationship between the effective number of parliamentary parties (ENPPs) and FDI inflows. Large ENPPs are indicative of the expropriation risks as well as stability of the political environment of host countries. We thus argue that expropriation risks are low when the presence of multiple parties makes drastic, impulsive changes in economic policies difficult. We also suggest that a larger number of parties represent diverse societal interests better, reducing the chances of under-represented social groups driving political instability. The relationship between ENPP and FDI inflows is tested on a sample of 56 developing democracies from 1985 to 2011. The evidence presented lends strong support to the argument and is found robust to a number of alternative empirical scenarios.
\end{abstract}

Keywords: FDI inflows, ENPP, party systems, democratic regimes.

\section{Introduction}

Firms operating across borders assign significant weight to political risks when considering hosts for their investments. Assessing political risks, however, often turns out to be a daunting challenge. Policymakers of host countries typically have a hard time credibly signaling their commitment to property rights protection to foreign investors (Buthe and Milner 2008) and as such a commitment is ultimately their private information. Literature on foreign direct investment (FDI) implies that good governance alleviates this commitment problem and, subsequently, renders national economies conducive to foreign capital inflow. A swath of empirical studies in recent years find empirical regularities between investment and quality of governance in the realm of strong judicial systems and rule of law (Staats and Biglaiser, 2012), effective corruption control (Barassi and Zhou, 2012), and the protection of civil and political rights (Harms and Ursprung, 2002), to name a few.

While this line of research significantly advances our understanding of how potential investors assess political risks of host countries, we suggest that the analytic utility of quality of governance indicators is limited. These indicators are predicated on relatively subjective and opaque coding decisions, delivering noisy signals of the host governments' commitment (Michener, 2015). We instead propose that the FDI literature can benefit from utilizing a core institutional trait of democratic politics, party systems of host countries in general and effective number of political parties (ENPP) in particular. Parties serve as political representatives, are involved in policy-making, and consequently play an important role in influencing FDI inflows (Simmons et al., 2018). For potential investors, how many actors hold the reins of power is an important consideration and ENPP is indicative of the number of actors who can influence policies at critical junctures of legislative processes. Moreover, the foremost analytical advantage of tapping into ENPP in host countries lies in its high observability to potential investors. Unlike the performative indicators of quality of governance, ENPP is easily observable and not subject to arbitrary coding decisions.

We test the relationship between ENPP and FDI inflows on a sample of 56 developing democracies. Our empirical analysis is two-fold. We first show the direct relationship between ENPPs and FDI through simple panel regression models. We, then, complement these models with a causal mediation analysis where we demonstrate that the effect of ENPP indeed runs through our two mediating factors, namely, expropriation risks and political stability. The result of our empirical analysis lends strong support to our argument and is found robust to alternative empirical scenarios.

The findings of this paper make a distinct contribution to the research on FDI inflows as well as ENPP. First, our focus on party systems enables us to highlight the heterogeneity of developing democracies in terms of FDI inflow, thereby advancing the literature beyond its traditional focus on regime-type and quality of governance. More specifically, we 
This is an author-produced, peer-reviewed version of this article. The final, definitive version of this document can be found online at Political Studies, published by SAGE. Copyright restrictions may apply. doi: 10.1177/0032321718799015

link an important institutional feature, namely, ENPP, to governmental policy stability and low expropriation risk, both important attributes for potential investors especially in the context of developing countries. Second, the use of ENPP goes beyond the purview of studies on FDI and offers a fresh look at the importance of simple institutional configurations in the broader field of the political economy of development. Unlike traditional studies seeking traits of quality of governance such as corruption control (e.g., Johnson et al., 2002) or those relying on empirical instruments such as settler mortality (Acemoglu et al., 2001), we suggest that the structure of political institutions clearly represent the limits of core policymakers' influence over the governing environment in a straightforward manner. Finally, we expand the scope of the studies on ENPP. A growing body of research focuses on the consequences of party systems where the significance of ENPP has been linked to crucial outcomes such as welfare expenditures (Crepaz 1998) and health outcomes (Wigley and Akkoyunlu-Wigley 2011a; Mukherjee 2013). We contribute to this literature by highlighting that the role of ENPP is not just restricted to domestic political economic outcomes but extends to international political economic outcomes such as foreign direct investments.

Our paper is comprised of six sections. In the section following this introduction, we explore existing studies on FDI inflow and point out that the current FDI scholarship can benefit from more contextualized insights on the effect of political party systems of host countries in the developing world. In the third section, we offer our argument that fills this lacuna and derive testable hypothesis from it. The fourth section outlines the empirical strategy and the fifth section presents the findings. The last section reviews these findings and discusses policy implications and our contribution to the existing literature.

\section{Literature Review}

Extant literature on the politics of FDI inflows can be summarized into two broad strands of research where the first focuses on differences between political regimes (e.g., Jensen 2003; Li 2006; Oneal 1994; Mathur and Singh 2013) whereas the second analyzes institutional determinants (e.g., Staats and Biglaiser 2012; Barassi and Zhou 2012; Harms and Ursprung 2002; Blanton and Blanton 2007; Moon 2015) that transcend a regime-type explanation. The first strand of research, which preceded the second, was in a nutshell an attempt to encapsulate political determinants of FDI into political regime types. Focusing on the relative advantages of democratic versus non-democratic regimes in their ability to attract greater FDI inflows, this line of research is composed of two contending perspectives. One perspective postulates that non-democracies are able to attract higher levels of foreign investment primarily because nondemocratic leaders are sheltered from societal pressure and are thereby able to provide foreign investors with better benefits and inducements as compared to democracies (Huntington 1968). Fewer institutional constraints make leaders more likely to pursue policies that could advance the interests of potential investors. Democratic officials, on the other hand, cannot permit foreign investors to function unrestrained in the domestic market, especially if domestic interests are likely to be compromised. ${ }^{i}$ Frequent leadership changes via popular elections amplify this limitedness of democracies ( $\underline{\mathrm{Li}}, \underline{2009})$.

Empirical evidence supporting the advantage of non-democratic regimes is abound. For instance, Oneal (1994) demonstrates that returns to investments are higher among non-democracies than democracies while Resnick's (2001) findings indicate that democratic transitions push away foreign investors. Pinto (2012) provides a more nuanced analysis, suggesting that democracies raise the expropriation risks of foreign investors when, but only when, the investors' interests are incompatible with that of their core constituents.

An alternative theoretical perspective postulates that democracies have a more advantageous position as compared to non-democracies for two primary reasons. The first is that they are able to provide formal and legal channels through which foreign investors can approach host governments and negotiate the terms of investments in a transparent manner (Jensen, 2008). This familiarizes potential investors with the process and reduces ambiguities about decision-making in host governments.

Second, democracies can attract higher levels of FDI than non-democracies because democratic institutions are more protective of property rights. Since democratic regimes can restrain governments from appropriating the private property of their citizens, foreign investors are better assured that the government will not capture their assets ( $\underline{\mathrm{Li}}$, 2006; Jensen, 2003). On the other hand, non-democratic leaders, generally, are less constrained by the rule of law and officials may display predatory tendencies towards private properties, including those of foreign investors (Ahlquist, 2006; Jensen, 2003; Jensen, 2008). Overall, theoretically sound arguments have been made in favor of both regimetypes and each enjoys considerable empirical support. 
This is an author-produced, peer-reviewed version of this article. The final, definitive version of this document can be found online at Political Studies, published by SAGE. Copyright restrictions may apply. doi: 10.1177/0032321718799015

Reflecting on these two seemingly contradicting perspectives on the effect of regime types, a second strand of research emerged. This line of research focuses on the functional elements of political institutions---quality of governance, that is---that transcend regime-type explanations. ${ }^{\text {ii }}$ Barassi and Zhou (2012) analyze the effect of a range of governance factors on FDI inflows such as corruption, government stability, internal and external conflict, law and order, and quality of bureaucracy, among others. Similarly, Staats and Biglaiser (2012) show that institutional features undergirding judicial strength and rule of law are strong determinants of FDI inflow in Latin America. Other scholars employ proxies for the quality of governance that attract FDI, arriving at similar conclusions. For instance, Harms and Ursprung (2002) and Blanton and Blanton (2007) find that countries with more respect for civil-political freedom and human rights, which would signal to the market policy stability and efficiency, are associated with greater FDI inflows. Similarly, Moon (2015) focuses on non-democratic regimes and argues that non-democratic governments with a longer time horizon can signal better protection of property rights and are able to attract higher FDI.

While the development from the first to the second strand of research significantly improved our understanding of politics of FDI inflow, the analytical utility of the quality of governance indicators in the second strand is limited in two dimensions. First, these indicators are often noisy signals of host governments' commitment to property rights protection. Based almost exclusively on 'expert surveys,' the external validity of these highly subjective indicators is frequently challenged (Michener, 2015; Apaza, 2009), particularly in the context of developing countries (Arndt, 2008). In capturing investors' perception of host countries' political risks, drawing on these indicators increases the possibility of measurement errors.

Second, we view that quality of governance is in essence an analytical tool more useful to highlight the difference between developed and developing countries than the difference amongst developing countries. Given the conventional wisdom that quality of governance tends to be correlated significantly with the level of development (e.g., Clague et al., 1996), the variation of FDI inflow among developing countries should be significantly smaller than that in a global sample.

[Figure 1 about here]

Figure 1 illustrates this contextual limitation. Here, the effect of the level of corruption control (left panel) and rule of law (right panel) using International Country Risk Guide (ICRG) data (PRS Group, 2011), two of the popular proxies for quality of governance, on FDI inflow is much greater in a global sample including both developed and developing economies than in a developing country-only sample. The slope of the global sample (dashed line) in each panel is notably steeper than that of the developing country-only sample (solid line). Existing studies do seem to be aware of this limitation of governance indicators as many of them check robustness of the main findings on a sample of developing countries (e.g., Jensen 2003). In short, our reading of the FDI literature suggests that to explain FDI inflow in the context of developing countries more effectively, one needs to focus on an alternative institutional attribute that is not subject to arbitrary coding decisions and unrelated to the level of development.

\section{The Relationship between ENPP and FDI}

Potential investors pay close attention to the domestic governing environment of host countries, as such an environment reveals information directly relevant to protecting their investments. We posit that investors are particularly concerned about the political risks of developing economies. As Ahlquist (2006: 682) succinctly points out, developing and developed nations exhibit marked differences when it comes to the policy uncertainties and the resultant risks investors have to bear. Political information, therefore, is particularly likely to affect investors' consideration of developing countries as hosts of their investments.

One of the observable attributes of host countries that may give investors valuable insights into the governing environment in a relatively unequivocal manner is the number of political parties in the legislature. In particular, we propose that effective number of political parties (ENPP) offers investors information on two important subjects, namely, 1) the likelihood of their investment unduly expropriated (expropriation risk) as well as 2) the extent of political representation as it relates to policy stability (representation). As such, we argue that there is a positive relationship between the effective number of political parties (ENPP) and the level of foreign direct investment inflow given that a high ENPP is indicative of a secure investment environment with low expropriation risk and a better represented society that signals greater policy stability. Below, we discuss our reasoning behind this argument. 
This is an author-produced, peer-reviewed version of this article. The final, definitive version of this document can be found online at Political Studies, published by SAGE. Copyright restrictions may apply. doi: 10.1177/0032321718799015

First, political parties function as one of the most effective veto players in legislative processes. The number of political parties in this sense indicates the plausibility of a sudden policy change (Tsebelis, 1995). Very low ENPP indicates high discretion of a small number of parties at adopting and implementing economic policies. Policy discretion amplifies the likelihood of opportunistic, predatory policies such as surprise devaluation (Weymouth, 2011) or debt default (Saiegh, 2009) with relatively weak resistance from the opposition or coalition partners. This perception of high policy discretion bestowed upon the majority party reduces the government's credibility on its commitment to maintain a favorable investment environment (such as low risk of expropriating private property). Such a policy unpredictability is likely to be a cause of concern for investors (MacIntyre, 2001). Of emphasis here is not what the government intends, but what investors perceive to be problematic about governments with fewer parties.

Second, very low ENPPs connote low levels of representation as well. Parties function as competitive agents of societal actors and provide an opportunity for societal preferences to influence legislation. Hence, the number of political parties is a useful indicator of the diversity of societal interests (not) effectively represented in legislation, providing investors with general insights into the economic policymaking of a host country (Simmons et al., 2018). As Lijphart (2012) demonstrates, the fact that very few political parties exist in the parliament suggests that the interests of diverse political groups are likely excluded from public policy making. Under-representation and exclusion often lead to low government responsiveness to societal groups (Hobolt and Klemmensen, 2008) and, subsequently, brew grievance. Grievance in turn has potential to escalate into drastic political changes, particularly in developing countries' contexts (Hegre et al., 2001). The possibilities of such grievance-driven political changes shy away investors (Blanton and Blanton, 2007: 144) as the alteration of political climates renders the return to their investment unpredictable. Overall, investors may view too little (low ENPP) representation with caution as it could threaten policy stability.

In contrast, expropriation risks stemming from policy discretion is relatively low in countries with higher ENPPs given the procedural difficulties in implementing drastic policy changes with a larger number of influential actors in the legislature. In principle, any policy proposals will need to be discussed among multiple groups in the legislature before policy changes can be made, thereby reducing the likelihood of reckless decisions. Higher ENPP may alleviate the risks associated with impulsive policy changes. In other words, higher ENPPs can signal to potential investors the presence of a favorable investment environment. It is worth noting here that our argument on the effect of political parties on FDI inflows is consistent with the veto player argument (Choi and Samy, 2008; Jensen, 2003). A higher number of parties in the legislature in our analysis, in other words, can be likened to the number of veto players in the literature. This paper, however, diverges from the traditional veto-player research by identifying the number of specific veto players, namely, legislative actors, that is informative of political risks of developing countries. Therefore, our focus on ENPP provides a fine-grained understanding of the politics of FDI.

A country with high ENPP is also more representative in nature (Lijphart 2012), where alternative views within society have a platform to influence policy-making within the confines of the legislature. Events that may feed violence and sudden changes in the government are less likely in countries with high ENPPs than in those with low ENPPs. This signals to the investors predictability and stability of government policies.

One could argue that high ENPPs are detrimental to attracting foreign investors because high levels of representation preclude host governments from offering "generous financial and fiscal incentives" (Li and Resnick 2003, 177) at the expense of the interests of median voters. While this is plausible, we note that 1) many investors may have other considerations besides prioritizing local incentives (Kucera 2002, Blanton and Blanton 2007) and 2) even when they do pursue such incentives, lower ENPPs suggest a higher risk that those incentives are abruptly stripped away by impulsive decisions of policymakers who are less constrained by the legislature.

Based on this discussion, we hypothesize that higher ENPPs are associated with larger volumes of FDI inflows. We expect that this relationship is much weaker, if any, in the context of developed economies. In advanced democracies, investors do not necessarily have to resort to ENPP to learn of the political climate of the host countries. However, in developing countries where information revealing governments' commitment to property rights is relatively scarce, we argue that ENPP is a useful indicator of investment climate and policy stability. ${ }^{\text {iii }}$

[Figures 2 and 3 here] 
This is an author-produced, peer-reviewed version of this article. The final, definitive version of this document can be found online at Political Studies, published by SAGE. Copyright restrictions may apply. doi: 10.1177/0032321718799015

Before turning to the research design, we present two illustrative case narratives that help us contextualize our theoretical argument in a real-world setting. Consider, first, the case of Venezuela. Chavez's reign as President from 1999 to 2013 was marked by large-scale nationalization schemes which influenced international investors such as the Spanish-owned bank, Banco de Venezuela, the cement industry which affected Mexican-based Cemex, as well as the wholesale fuel sector where companies like ExxonMobil, BP, and Chevron also held stakes in the fuel distribution market (Oxford Analytica, 2008). While the political ideology of Chavez can help account for his policy decisions but the speed with which these nationalizations were implemented would not have been possible had there been high ENPPs during this period, which would have stemmed the swift policy revisions. As seen in Figure 2, the dramatic policy changes coincided with a drastic decline in ENPP (solid line) and reduction in FDI (dashed line) from USD 6 billion in 1997 (before his election) to USD 1.7 billion in 2004 to negative values in 2006. Low ENPPs implied that Chavez's aggressive policies could not be checked and would eventually affect their investment.

Another illustrative case is Albania. Until 1997, the Democratic Party was a dominant political force in the parliament as it enjoyed a strong anti-communist mandate despite its largely unpopular policies (Kajsiu, 2010). Foreign capital, however, was hesitant to invest in the country, citing the rampant corruption and political instability (Bitzenis and Szamosi, 2009: 196) that was largely condoned by the Democratic Party. The 1997 pyramid scheme scandal warranted this concern and the volume of FDI inflow was staggering until the late 1990s despite the initiation of drastic pro-FDI reform packages (Alexious and Toro, 2006: 75). The aftermath of scandal, however, altered the existing political landscape of the country, bringing the traditional opposition party, the Socialist Party, in power in 1997 as well as enabling the rise of the third major party, the Republic Party of Albania. The reform policies adopted seem to have become more credible during this time as the FDI inflow increased exponentially. ${ }^{\text {iv }}$ The representation of different societal groups in parliamentary politics also improved, albeit through invoking "negative identities," primarily as a result of the increased competition between the major parties in the 2000s (Kajsiu, 2010: 247). As the electoral results in the subsequent years imply (Figure 3), this enhanced representation led to political processes that were much more predictable than before. Over the years both ENPP and FDI have been increasing, which enhanced the perception of policy stability for potential investors.

\section{Data \& Methods}

This paper assesses the relationship between ENPP and FDI inflows on a sample of 56 developing democracies from 1985 to 2011. The dependent variable is FDI inflows measured as the natural logarithm of FDI inflows in US dollars. An alternative way of measuring FDI inflows is FDI as a percentage of GDP. The two measures tap into different aspects of FDI inflows $(\underline{\mathrm{Li}}, \underline{2009})$. The former captures the overall size of inflows while the latter gives an indication of the size of inflow relative to the host economy. Since we are primarily interested in the former, we choose the logged value of FDI inflows in US dollars over FDI/GDP as our primary dependent variable. The data come from UNCTAD (United Nations Conference on Trade and Development). ${ }^{v}$ Consistent with other studies (e.g., Moon, 2015) we transform the logged value of the FDI variable to account for 0 and negative values of FDI in the following way:

$$
\left\{\begin{aligned}
\text { If } F D I \geq 0, \quad \ln (F D I) & =\log (1+F D I) \\
\text { If } F D I<0, \ln (F D I) & =-\log (1+|F D I|)
\end{aligned}\right.
$$

The primary independent variable is a natural logarithm of ENPP. Natural log is taken not only because of the skewed distribution of ENPP data but also due to our expectation that the marginal effect of ENPP diminishes as ENPPs increase following Heinsz (2004: 10). In a political system with very many parties, an increase of ENPP by one would not make a difference whereas any increase in ENPP in a single party system should. The data come from Bormann and Golder (2013). ${ }^{\text {vi }}$

We control for alternative factors taken into account in most FDI studies. The economic variables include GDP per capita, oil rent as a percentage of GDP, volume of trade as a percentage of GDP, and final consumption expenditure as a percentage of GDP. GDP per capita, oil as a percentage of GDP, and trade as a percentage of GDP are expected to be positively associated with FDI inflows. The effect of final consumption expenditure is more uncertain (Jensen 2003, 2004; Büth and Milner, 2008; Moon, 2015). Population is also controlled for. We expect countries with larger populations to attract greater inflows. Data for these variables come from the World Development Indicators (WDI) of the World Bank (2015). 
This is an author-produced, peer-reviewed version of this article. The final, definitive version of this document can be found online at Political Studies, published by SAGE. Copyright restrictions may apply. doi: 10.1177/0032321718799015

Aside from macroeconomic covariates, we control for the level of democracy. We use the polity data set (Marshall, Gurr and Jaggers, 2014) given that a large number of studies analyze the effect of regime-type on FDI inflows. The polity2 variable ranges from -10 to +10 where higher values indicate a higher level of democracy. ${ }^{\text {vii }}$ In addition, we also control for the level of corruption control using the data from the International Country Risk Guide (PRS Group, 2011). We expect corruption control to be positively associated with FDI inflows. In order to ward off serial correlations in the error-term, whose degree we assume varies across countries given the unbalanced structure of our panel data, panel-specific first-order autoregressive disturbance (PSAR(1)) is applied. Likewise, given the panel heteroskedasticity, we employ panel-corrected standard errors (Beck and Katz, 1995). Finally, we take a country-fixed effect approach to account for the unobserved case-specific idiosyncrasies. Therefore, the benchmark results, as Bell and Jones (2015) suggest, is more indicative of within-case effects of ENPP than between-case effects. All independent variables are lagged by a year to avoid the possibility of reverse causality and allow the time for our causal mechanism to operate. It is worth noting here that we obtain results largely identical to the benchmark result even when independent variables are not lagged and instead contemporaneous values are taken. This alleviates the concern that lagging independent variables could lead to incorrect inference (Bellemare, Masaki, and Pepinski, 2017). Descriptive statistics for these variables are provided in Table $\underline{1}$.

Using these variables, we can formally write the linear model to test our hypothesis as following:

$$
\text { Benchmark Model : } \ln (F D I) i t=\beta 1 \ln (E N P P) i t-1+\beta n \Sigma C O N T R O L S i t-1+v i+\varepsilon i t
$$

where $\beta \mathrm{s}$ are coefficients, $v$ fixed effect term, $\varepsilon$ the error term, ' $i$ ' country, and ' $\mathrm{t}$ ' year. Should our hypothesis be supported, $\beta 1$ should be significantly positive.

Our choice of 'developing democracies' as opposed to a global sample deserves some clarification here. The 'developing' refers to our exclusive focus on non-OECD economies while 'democracy' or electoral democracy refers to a system in which elections exist with a certain, but not necessarily complete, level of fairness and competitiveness (Diamond, 2002). In monarchies with political parties composed of elected legislators, ENPP cannot exist conceptually. These cases do not register as 'democracies' in our study to maintain unit homogeneity in the sample. In practical terms, our sample includes both liberal democracies and hybrid regimes. This enables us to take advantage of existing variations in political representation across developing democratic countries.

\section{Findings}

\section{Benchmark Results}

[Table 2 here]

Table 2 contains the result of estimating our benchmark model. The significantly positive coefficient of $\ln (\mathrm{ENPP})$ in model (3) with all the controls and fixed effects suggests that as proposed in our hypothesis, increases in ENPP lead to increases in FDI inflows. Given that both the independent and dependent variables take natural logs, we can infer from this result that a one percent increase in ENPP leads to about 0.7 percent increase in FDI inflow. A graphical representation of this effect, Figure 4, demonstrates the diminishing marginal returns of this effect. The figure implies that while the change from a dominant party system (i.e., ENPP=1) to a competitive three-party system (i.e., ENPP=3) generates a significant increase in FDI inflows, a similar move from a seven-party system to a nine-party system does not significantly contribute to attracting foreign capital.

\section{[Figure 4 here]}

The results of other models in Table 2 bolster our confidence in this result. First, there does not exist a qualitative difference between Model (1), where all the control variables are excluded, and the benchmark model in terms of the effect of $\ln ($ ENPP). This indicates that the hypothesized effect of $\ln ($ ENPP) does not operate substantively through any of our control variables. Similarly, when fixed effects are lifted (Model 2), the benchmark effect of ln(ENPP) still persists. We infer from this result that our primary result is not a statistical artifact of using fixed effects (Gibbons et al. 2018). 
This is an author-produced, peer-reviewed version of this article. The final, definitive version of this document can be found online at Political Studies, published by SAGE. Copyright restrictions may apply. doi: 10.1177/0032321718799015

\section{Causal Mediation Analysis}

As depicted in Figure 5, our argument about the effect of ENPP on FDI inflow is predicated on two mediating factors, namely, expropriation risks and policy stability. Investors are concerned about unchecked impulsive policies leading to expropriation of their properties as well as underrepresentation of societal groups resulting in policy instability. If we find evidence pointing to this mechanism, our confidence in the benchmark result supporting the effect of ENPP can be further bolstered.

\section{[Figure 5 about here]}

Methodological problems limit the extent to which we investigate this mediation effect. To the best of our knowledge, there are no data directly capturing investors' perceptions on the expropriation risk and political representation of societal actors in a host country whose coverage is comprehensive enough to include the cases of our sample. As an alternative, we employ two variables from ICRG (PRS Group, 2011) that we believe best proxy these two mediating factors: Investment Profile and Government Stability. Investment Profile consists of three indicators of investor perceptions on expropriation practices such as 'contract viability/expropriation,' 'profits repatriation,' 'and payment delays.' These variables tap into investors' perceived expropriation risks of the host country that are "not covered by other political ... components" (Howell, 2011: 3). Similarly, Government Stability contains investors perceived level of 'popular support for the government' in the host country (Howell, 2011). Support for the government should be low if societal actors are politically under-represented, thereby sowing the seeds for political instability.

If the benchmark result represents the causal mechanism we propose, higher ENPPs should reduce expropriation risks (high Investment Profile) and add to representativeness of governments (high Government Stability), each of which in turn leads to greater volumes of FDI inflows. This implies that the effect of ENPP on the mediating factors $(\alpha$ in Figure 5) and the effect of the mediating factors on FDI inflows ( $\beta)$, as well as their combined effects $(\alpha \times \beta)$, are all significantly positive.

\section{[Table 3 here]}

We follow Preacher and Hayes (2008) in computing the coefficients, namely, $\alpha, \beta$, and $\alpha \times \beta$ (or 'indirect effect'). One can obtain these coefficients simultaneously using a Seemingly Unrelated Regression model (Zellner 1962). Once these coefficients along with their standard errors are obtained, we can then compute the indirect effect for each causal path by computing their nonlinear combination $(\alpha \times \beta)$. In the model, we also include country fixed effects to maintain comparability between its result and the benchmark. To approximate first-order panel-specific autocorrelation term (PSAR 1) in the benchmark model, we include a lagged dependent variable (LDV) for each equation. Although applying fixed effects and LDVs simultaneously can wipe out the 'true' mediating effect to an excessive degree (Achen, 2000), we believe that this conservative specification serves our purpose of bolstering the confidence in our benchmark result.

Table 3 presents the result of mediation analysis. The significantly positive effect of the $\ln (\mathrm{ENPP})$ in the first equation as well as that of the mediators in the second equation confirms that the causal mediation depicted in Figure 5 is indeed at work. In particular, Table 3 reports that the 'indirect effect' presented as $\alpha \times \beta$ in Figure 5 is significantly positive in both mediation models, lending further support to our argument. The size of the mediating effect in each model compared to the total effect of ENPP on FDI (i.e., $\lambda /(\alpha \times \beta+\lambda)$ ) is not negligible (about $10 \%$ ) given our conservative specifications.

\section{Robustness Check}

\section{[Table 4 here]}

In this section, we report the result of robustness tests of our benchmark model to demonstrate that the methodological choices we made are warranted. The first of such is to use an alternative data for FDI inflows. While we believe that UNCTAD FDI data are generally more accurate and comprehensive than that provided by WDI, the general pattern of the statistical result using the benchmark specification should be unchanged even if we use the latter. Model (1) of Table 4 indeed reports exactly that. When the WDI data are used, the size of coefficient actually increases although the level of significance decreases slightly. 
This is an author-produced, peer-reviewed version of this article. The final, definitive version of this document can be found online at Political Studies, published by SAGE. Copyright restrictions may apply. doi: 10.1177/0032321718799015

Another possible concern might be our handling of possible serial correlations in the error term. While panel-specific first-order autoregressive disturbance (PSAR(1)) we use might be a reasonable way to curtail the influence of serial correlations, we do note that many of the existing studies utilizing FDI panel data follow a lagged dependent variable (LDV) approach. Although in theory PSAR(1) and LDV models should yield fairly similar estimates, we can be more confident in our results if the linear effect of ENPP is unchanged when taking an LDV approach, which is more restrictive than PSAR(1). Model (2) presents the result of a model using an LDV, which proves the concern over the PSAR(1) approach was unwarranted.

A similar concern is our measure of FDI inflow. While we are more interested in the size of FDI inflow than its relative importance in the host economy, we acknowledge that there hardly is a consensus that a natural logarithm is the right representation of the former. We therefore use an alternative FDI measure, namely FDI inflow as percentages of GDP. The result reported in Model (3) indicates that our benchmark result is robust to this change of operationalization of the dependent variable. Finally, we consider applying different 'thresholds' for our definition of democracy. Our sample consists of both fully and partially democratic countries. One could argue that the effect of party systems can vary across different levels of democracy, however. It is thus plausible that our benchmark result conflates two different processes in which ENPP affects FDI inflows. Models (4) and (5) of Table 4 affirm that this concern is unwarranted. When the sample is limited to fully democratic cases (Model 4), which we define as countries whose polity scores are nine or ten, the benchmark result is not altered. Likewise, when using a sample for observations where polity is limited to eight or lower (Model 5), we find a result qualitatively not different from the benchmark despite the slightly weaker significance level. Applying a different threshold of polity index leads to similar results.

Beyond measurement issues, a plausible concern can be raised over our use of a fixed effect model as a benchmark. While the Hausman test result suggests that fixed effect model is preferred $(\chi 2(9)=77.62, p=0.000)$, fixed effect models are not without shortcomings. In particular, if ENPPs change infrequently and slowly over time ('time-invariant'), using country fixed effect models would unduly wipe out the cross-country variations in FDI. Bell and Jones (2015) suggest a straightforward way to address this concern, which essentially boils down to rendering the estimates 'flexible.' As Bell and Jones (2015) suggest, we included country-mean variables for independent variables as well as their difference from each of the individual observations at the current year $(\mathrm{t})$ in a random effect generalized least squares model. To put it formally, Model (2) can be revised:

$$
\begin{aligned}
& \ln (F D I) \text { it }=\beta_{1} \ln \left(E N P P^{\text {mean }}\right)_{\mathrm{it}-1}+\beta_{2}\left[\ln (E N P P)_{\mathrm{it}-1}-\ln (E N P P)^{\text {mean }}{ }_{\mathrm{i}}\right] \\
& +\beta \Sigma \text { CONTROLS } \text { mean }_{\mathrm{it}-1}+\beta \Sigma\left(\text { CONTROLS }_{\mathrm{it}-1}-\text { CONTROLS }^{\text {mean }}{ }_{\mathrm{i}}\right)+\varepsilon_{\mathrm{it}}
\end{aligned}
$$

The coefficient for the mean variable $\left(\beta_{1}\right)$ is expected to explicitly account for the 'between' effects whereas the coefficient for the difference term $\left(\beta_{2}\right)$ is set to represent the 'within' effect (Bell and Jones 2015,141$)$. The result on the within-country effect presented in Table 5 is largely consistent with our benchmark fixed effect model in that the effect of $\ln (\mathrm{ENPP})$ is positively significant. The between-country effect on the other hand is insignificant, suggesting that our inference on the relationship between ENPP and FDI pertains more to inter-temporal comparisons within a country (hence our illustrative case studies) than to inter-country comparisons.

[Table 5 here]

[Table 6 here]

Finally, we include additional controls such as judicial independence, presidential systems and conservative governments to see if they somehow compound the effect of ENPP. ${ }^{\text {vii }}$ We also account for the temporal trends of FDI inflows by including two variables capturing year of each observation and its square term (that is, year ${ }^{2}$ ). In a separate model, we also experimented with the effect of applying country-specific time trends to the benchmark model. Table $\underline{6}$ demonstrates that our benchmark result is robust to these empirical possibilities. Taken together, a range of robustness tests we implemented demonstrate that ENPP has a statistically significant effect on FDI inflows among developing countries. Models 1 through 3 indicate that the inclusion of additional control variables does not alter the benchmark result. Likewise, the benchmark result proves to be robust to accounting for the general temporal trend (Model 4) and country-specific trends (Model 5). 
This is an author-produced, peer-reviewed version of this article. The final, definitive version of this document can be found online at Political Studies, published by SAGE. Copyright restrictions may apply. doi: 10.1177/0032321718799015

\section{Conclusion}

This paper highlights the domestic determinants of FDI inflows among developing democracies. We underline the fact that parties are the major agents of policy making in modern democratic politics. Their central role of aggregating and mobilizing collective policy preferences is the centerpiece of everyday politics, particularly in policy-making, policy implementation, and monitoring. Thus, the nature of party systems of a host country can be an important source of information to potential investors about the political environment. More specifically, we argue that ENPPs reflect critical information about the investment climate and the extent of political representation, both of which are imperative considerations to potential investors.

We demonstrate that ENPP has a positive relationship with FDI inflows where higher ENPP is associated with higher levels of FDI inflows. High ENPP presents a favorable investment climate with low expropriation risk and a better represented society that enhances policy stability. The presence of multiple parties in the legislature reduces the likelihood of reckless decisions by governments, providing a low-risk and a stable political environment to investors.

Overall, we add to the emerging research that goes beyond a regime-type explanation to better understand the dynamics between political institutions and FDI inflows. More generally, we contribute to the larger literature in political science that adopts a disaggregated approach by identifying specific regime characteristics such as political institutions to explain a wide range of well-being outcomes (Bueno de Mesquita et al. 2003; Gerring, Thacker, and Moreno 2005, 2009; Kudamatsu 2012; Wigley and Akkoyunlu-Wigley 2011a, 2011b; Mukherjee 2013).

The study has important policy implications that may be of interest to potential host countries, especially in the developing world. Extant literature establishes that investors take the political environment into consideration before making a decision to invest. Our findings imply that in the context of developing democracies where information about policymaking is generally scant (Hollyer, Rosendorff and Vreeland 2014), ENPP offers investors a fairly useful gauge of how politics might affect their investment. We provide a nuanced understanding of the determinants of FDI among developing countries by going beyond regime-type and identifying political factors that shed light on the variation in FDI inflows in the developing world.

\section{Acknowledgements}

Both authors contributed to the article equally. Byunghwan Son thanks Taehwan Kim for encouraging him to pursue the project. Both authors thank Jonathan Krieckhaus and Myunghwa Cho for their feedback on previous versions of the article and Cassie Adams for her research assistance.

\section{References}

Acemoglu, Daron, Simon Johnson, and James Robinson. (2001.) The Colonial Origins of Comparative Development: An Empirical Investigation. American Economic Review 91: 1369-1401.

Achen, Christopher. H., 2000. Why lagged dependent variables can suppress the explanatory power of other independent variables. Unpublished working paper. Ann Arbor, University of Michigan.

Ahlquist, John S. (2006.) Economic Policy, Institutions, and Capital Flows: Portfolio and Direct Investment Flows in Developing Countries. International Studies Quarterly 50(4): 681-704.

Alexiou, Constantinos and Doriana Toro. (2006.) FDI Revisited: Empirical Evidence from Transition Economies Case of Albania. Zagreb International Review of Economics \& Business 9(2): 59-94.

Apaza, Carmen R. (2009). Measuring governance and corruption through the worldwide governance indicators: Critiques, responses, and ongoing scholarly discussion. PS: Political Science \& Politics 42(1): 139—143.

Arndt, Christiane. (2008.) The politics of governance ratings. International Public Management Journal 11(3): 275-297.

Barassi, Marco R. and Ying Zhou. (2012.) The effect of corruption on FDI: A parametric and non-parametric analysis. European Journal of Political Economy 28(2): 302-312.

Beck, Horsetn, George Clarke, Alberto Groff, Philip Keefer and Patrick Walsh. (2001.) New Tools in Comparative Political Economy: Database of Political Institutions. World Bank Economic Review 15(1): 165-176.

Beck, Nathaniel and Jonathan N. Katz. (1995.) What to Do (And Not to Do) with Time-Series Cross-Section Data. American Political Science Review 89(3): 634-647.

Bell, Andrew and Kelvyn Jones. (2015.) Explaining Fixed Effects: Random Effects Modeling of Time-Series CrossSectional and Panel Data. Political Science Research and Methods 3(1): 133-153. 
This is an author-produced, peer-reviewed version of this article. The final, definitive version of this document can be found online at Political Studies, published by SAGE. Copyright restrictions may apply. doi: 10.1177/0032321718799015

Bellemare, Marc F., Takaaki Masaki, and Thomas B. Pepinsky. (2017.) Lagged Explanatory Variables and the Estimation of Causal effect. Journal of Politics 73(3): 949-963.

Bitzenis Aristidis and Leslie T. Szamosi. (2009.) Entry Modes and the Determinants of Foreign Direct Investment in a European Union Accession Country: The Case of Albania. Journal of East-West Business 15: 189-209.

Blanton, Shannon Lindsey and Robert G. Blanton. (2007.) What Attracts Foreign Investors? An Examination of Human Rights and Foreign Direct Investment. Journal of Politics 69(1): 143-155.

Bormann, Nils-Christian and Matt Golder. (2013.) Democratic Electoral Systems Around the World, 1946-2011. Electoral Studies 32:360-369.

Bueno de Mesquita, Bruce, Alastair Smith, Randolph M. Siverson, and James D. Morrow. 2003. The Logic of Political Survival. Cambridge: MIT Press.

Büth, Tim and Helen V. Milner. (2008.) The Politics of Foreign Direct Investment into Developing Countries: Increasing FDI through International Trade Agreements? American Journal of Political Science 52(4): 741-762.

Choi, Seung-Whan and Yiagadeesen Samy. (2008.) Reexamining the Effect of Democratic Institutions on Inflows of Foreign Direct Investment in Developing Countries Foreign Policy Analysis 4(1): 83-103.

Cingranelli, David L and David L Richards. (2010.) The Cingranelli and Richards (CIRI) human rights data project. Human Rights Quarterly 32(2): 401-424.

Clague, Christophe, Philip Keefer, Stephen Knack, and Mancur Olson. (1996.) Property and Contract Rights in Autocracies and Democracies. Journal of Economic Growth 1(2): 243-276.

Crepaz, Markus M.L. (1998). Inclusion and Exclusion: Political Institutions and Welfare Expenditures. Comparative Politics 31(1): 61-80.

Dahl, Robert Alan. (1973.) Polyarchy: Participation and opposition. New York, NY: Yale University Press.

Diamond, Larry J. (2002.) Thinking About Hybrid Regimes. Journal of Democracy 13(2):21-35.

Gerring, John, Strom C. Thacker, and Carola Moreno. 2005. "Centripetal Democratic Governance: A Theory and Global Inquiry.” American Political Science Review 99 (4): 567-81.

Gerring, John, Strom C. Thacker, and Carola Moreno. 2009. “Are Parliamentary Systems Better?” Comparative Political Studies 42 (3): 327-359.

Gibbons, Charles E, Juan Serrato, Carlos Suárez, and Michael B. Urbancic. (2018.) Broken of Fixed Effects? Journal of Econometric Methods. Forthcoming. DOI: https://doi.org/10.1515/jem-2017-0002.

Harms, Philipp and Henrich W. Ursprung. (2002.) Do Civil and Political Repression Really Boost Foreign Direct Investments? Economic Inquiry 40(4): 651-663.

Hegre, Håvard, Tanja Ellingsen, Scott Gates and Nils Petter Gleditsch. (2001.) Toward a Democratic Civil Peace? Democracy, Political Change, and Civil War, 1816-1992. American Political Science Review 95(1): 33-48.

Hobolt, Sara Blinzer and Robert Klemmensen. (2008.) Government responsiveness and political competition in comparative perspective. Comparative Political Studies 41(3): 309-337.

Hollyer, James R. and B. Peter Rosendorff and James Raymond Vreeland. (2014.) Measuring Democracy. Political Analysis 22: 413-434.

Howell, Llewellyn D. (2011.) International Country Risk Guide Methodology. East Syracuse, NY: PRS Group.

Huntington, Samuel P. 1968. Political Orders in Changing Societies. New York: Yale University Press.

Jensen, Nathan. (2008.) Political Risk, Domestic Institutions, and Foreign Direct Investment. Journal of Politics 70(4): 1040-1052.

Jensen, Nathan M. (2003.) Democratic Governance and Multinational Corporations: Political Regimes and Inflows of Foreign Direct Investment. International Organization 57: 587-616.

Jensen, Nathan M. (2004.) Crisis, Conditions, and Capital: The Effect of International Monetary Fund Agreements on Foreign Direct Investment Flows. Journal of Conflict Resolution 48(2): 194-210.

Johnson, Simon, John McMillan, and Christopher Woodruff. (2002.) Property Rights and Finance. American Economic Review 92(5): 1335-1356.

Kajsiu, Blendi. (2010.) Down with Politics! The Crisis of Representation in Post-Communist Albania. East European Politics and Societies. 24(2): 229-253.

Keefer, Philip and Stephen Knack. (2002.) Polarization, Politics and Property Rights: Links between Inequality and Growth. Public Choice 111(1): 127-154.

Kudamatsu, Masayuki. 2012. "Has Democratization Reduced Infant Mortality in Sub-Saharan Africa? Evidence from Micro Data.” Journal of the European Economic Association 10 (6): 1294-1317.

Kucera, David. (2002.) Core labour standards and foreign direct investment. International Labour Review 141(1): 31-69. 
This is an author-produced, peer-reviewed version of this article. The final, definitive version of this document can be found online at Political Studies, published by SAGE. Copyright restrictions may apply. doi: 10.1177/0032321718799015

Laakso, Markku and Rein Taagepera. (1979.) “Effective” Number of Parties: A Measure with Application to West Europe. Comparative Political Studies 12(1): 3-27.

Li, Quan. (2006.) Democracy, Autocracy, and Tax Incentives to Foreign Direct Investors: A Cross-National Analysis. Journal of Politics 68(1): 62-74.

Li, Quan. (2009.) Democracy, Autocracy, and Expropriation of Foreign Direct Investment. Comparative Political Studies 42(8): 1098-1127.

Lijphart, Arend. (2012.) Patterns of Democracy. New York, NY: Yale University Press.

MacIntyre, Andrew. (2001.) Institutions and Investors: The Politics of the Economic Crisis in Southeast Asia. International Organization 55(1):81-122.

Marshall, Monty G., Ted Robert Gurr and Keith Jaggers. (2014.) “POLITY IV Project: Dataset Users’ Manual.” Center for Systematic Peace: http://www.systemicpeace.org/polity/polity4.htm

Michener, Gregory. (2015.) Policy evaluation via composite indexes: Qualitative lessons from international transparency policy indexes. World Development 74: 184-196.

Moon, Chungshik. (2015.) Foreign Direct Investment, Commitment Institutions, and Time Horizon: How Some Autocrats Do Better than Others. International Studies Quarterly 59(2): 344-356.

Mukherjee, Nisha. 2013. "Party Systems and Human Well-Being.” Party Politics 19(4): 601-623.

Oneal, John R. (1994.) The Affinity of Foreign Investors for Authoritarian Regimes. Political Research Quarterly 47(3): 565-588.

Oxford Analytica. (2008.) https://www.forbes.com/2008/09/09/venezuela-chavez-nationalizationcx_0910oxford.html\#3bf7c8a919da

Pinto, Pablo M. (2012.) Partisan Investment in the Global Economy: Why FDI Loves the Left and the Left Loves FDI. New York, NY: Cambridge University Press.

Preacher, Kristopher J. and Andrew F. Hayes. (2008.) Asymptotic and resampling strategies for assessing and comparing indirect effects in multiple mediator models. Behavior Research Methods 40(3): 879-891.

PRS Group. (2011.) International Country Risk Guide. https://epub.prsgroup.com/products/icrg/icrg-historical-data

Resnick, Adam L. (2001.) Investors, Turbulence, and Transition: Democratic Transition and Foreign Direct Investment in Nineteen Developing Countries. International Interactions 27: 381-398.

Riker, William. (1965.) Democracy in America. New York, NY: Macmillan.

Saiegh, Sebastian M. (2009.) Coalition governments and Sovereign Debt Crises. Economics \& Politics 21(2): 232254.

Schmitter, Philippe C and Terry Lynn Karl. (1991.) What democracy is... and is not. Journal of democracy 2(3): 7588.

Simmons, Joel, Allen Hicken, Ken Kollman, and Irfan Nooruddin. (2018.) Party System Structure and It’s Consequences for Foreign Direct Investment. Party Politics 24(2): 141-153.

Staats, Joseph L. and Glen Biglaiser. (2012.) Foreign Direct Investment in Latin America: The Importance of Judicial Strength and Rule of Law. International Studies Quarterly 56(1): 193-202.

Tsebelis, George. (1995.) Decision Making in Political Systems: Veto Players in Presidentialism, Parliamentarism, Multicameralism and Multipartyism. British Journal of Political Science 25(3): 289-325.

Weymouth, Stephen. (2011.) Political Institutions and Property Rights: Foriegn Exchange Commitments in 127 Countries. Comparative Political Studies 44: 211-240.

Wigley, Simon, and Arzu Akkoyunlu-Wigley. 2011a. "Do Electoral Institutions have an Impact on Population Health?” Public Choice 148 (3-4): 595-610.

Wigley, Simon, and Arzu Akkoyunlu-Wigley. 2011b. "The Impact of Regime Type on Health: Does Redistribution Explain Everything?” World Politics 148(3-4): 595-610.

World Bank. (2015.) “World Development Indicators.” Washington D.C.: https://openknowledge.worldbank.org/handle/10986/21634.

Zellner, Arnold. (1962.) An efficient method of estimating seemingly unrelated regressions and tests for aggregation bias. Journal of the American statistical Association 57(298): 348-368. 
This is an author-produced, peer-reviewed version of this article. The final, definitive version of this document can be found online at Political Studies, published by SAGE. Copyright restrictions may apply. doi: 10.1177/0032321718799015

\section{Author Biographies}

Nisha Mukherjee Bellinger is Assistant Professor of Political Science in the School of Public Service at Boise State University. Her research focuses on political economic themes. She is the author of Governing Human Well-Being: Domestic and International Determinants (Palgrave Macmillan 2018) and her research appears in journals such as European Political Science Review, International Political Science Review, and Journal of Politics, among others.

Byunghwan Son is Assistant Professor of Global Affairs at George Mason University (Fairfax, USA). His work appears in journals such as Journal of Politics, Journal of Peace Research, and International Political Science Review, among others.

\section{Table 1. Descriptive Statistics.}

\begin{tabular}{lrcccc}
\hline \hline Variable & Mean & Std. Dev. & Min. & Max. & N \\
\hline $\ln ($ FDI) & 5.489 & 2.799 & -6.892 & 10.789 & 1118 \\
$\ln ($ ENPP) & 1.147 & 0.477 & 0 & 3.514 & 1118 \\
polity2 & 5.665 & 4.592 & -8 & 10 & 1118 \\
corruption & 2.525 & 0.893 & 0 & 5 & 1118 \\
Trade (\% GDP) & 66.588 & 34.607 & 12.009 & 321.632 & 1118 \\
Expenditure & 84.094 & 14.101 & 39.977 & 252.537 & 1118 \\
Oil rents (\% GDP) & 4.138 & 10.173 & 0 & 73.332 & 1118 \\
$\ln$ (population) & 16.402 & 1.509 & 12.85 & 20.91 & 1118 \\
$\ln$ (GDPpc) & 7.224 & 1.103 & 4.89 & 9.960 & 1118 \\
\hline
\end{tabular}


This is an author-produced, peer-reviewed version of this article. The final, definitive version of this document can be found online at Political Studies, published by SAGE. Copyright restrictions may apply. doi: 10.1177/0032321718799015

\section{Table 2. Benchmark Model}

\begin{tabular}{|c|c|c|c|}
\hline & $(1)$ & $(2)$ & (3) \\
\hline $\ln (\mathrm{ENPP})$ & $\begin{array}{l}1.330^{* * *} \\
{[0.296]}\end{array}$ & $\begin{array}{l}0.455^{* *} \\
{[0.189]}\end{array}$ & $\begin{array}{l}0.744^{* * *} \\
{[0.238]}\end{array}$ \\
\hline Polity2 & & $\begin{array}{l}0.049^{* *} \\
{[0.023]}\end{array}$ & $\begin{array}{l}0.051^{* *} \\
{[0.023]}\end{array}$ \\
\hline ln(GDP per capita) & & $\begin{array}{l}0.999^{* * *} \\
{[0.173]}\end{array}$ & $\begin{array}{l}0.818^{* * *} \\
{[0.232]}\end{array}$ \\
\hline Trade (\% of GDP) & & $\begin{array}{l}0.015^{* * *} \\
{[0.003]}\end{array}$ & $\begin{array}{c}0.007 \\
{[0.006]}\end{array}$ \\
\hline Oil Rents & & $\begin{array}{c}0.004 \\
{[0.011]}\end{array}$ & $\begin{array}{l}-0.054^{* *} \\
{[0.024]}\end{array}$ \\
\hline Consumption & & $\begin{array}{c}0.007 \\
{[0.007]}\end{array}$ & $\begin{array}{c}0.005 \\
{[0.009]}\end{array}$ \\
\hline Corruption & & $\begin{array}{l}0.236^{* *} \\
{[0.114]}\end{array}$ & $\begin{array}{l}0.397^{* * *} \\
{[0.121]}\end{array}$ \\
\hline $\ln$ (population) & & $\begin{array}{l}1.109^{* * *} \\
{[0.120]}\end{array}$ & $\begin{array}{l}6.524^{* * *} \\
{[0.863]}\end{array}$ \\
\hline Constant & $\begin{array}{l}4.285^{* * *} \\
{[0.955]}\end{array}$ & $\begin{array}{c}-23.114^{* * *} \\
{[2.573]} \\
\end{array}$ & $\begin{array}{c}-100.892^{* * *} \\
{[12.017]} \\
\end{array}$ \\
\hline Fixed Effects & Yes & No & Yes \\
\hline $\begin{array}{l}\text { Observations } \\
R^{2}\end{array}$ & $\begin{array}{l}1113 \\
0.612\end{array}$ & $\begin{array}{l}1113 \\
0.506\end{array}$ & $\begin{array}{l}1113 \\
0.629\end{array}$ \\
\hline
\end{tabular}

${ }^{*} p<0.10,{ }^{* *} p<0.05,{ }^{* * *} p<0.01$. OLS estimates with panel-corrected standard errors in brackets. Country fixed effects are applied but the result is abbreviated to save space. Panel-specific first-order autoregressive disturbances are applied. 
This is an author-produced, peer-reviewed version of this article. The final, definitive version of this document can be found online at Political Studies, published by SAGE. Copyright restrictions may apply. doi: 10.1177/0032321718799015

\section{Table 3. Causal Medication}

\begin{tabular}{|c|c|c|c|c|}
\hline \multirow{2}{*}{$\begin{array}{l}\text { Mediator } \\
\text { [Equation 1] }\end{array}$} & \multicolumn{2}{|c|}{ (1) } & \multicolumn{2}{|c|}{ Investment profile } \\
\hline & & & & \\
\hline LDV: Government Stabilityt-1 & $0.781^{* * *}$ & {$[0.018]$} & & \\
\hline LDV: Investment profile ${ }_{t-1}$ & & & $0.795^{* * *}$ & [0.018] \\
\hline $\ln (\mathrm{ENPP})$ & $0.261^{* *}$ & {$[0.110]$} & $0.182^{* *}$ & [0.088] \\
\hline Polity2 & -0.003 & [0.012] & 0.013 & [0.009] \\
\hline $\ln ($ GDP per capita) & $0.241^{* * *}$ & [0.092] & $0.361^{* * *}$ & {$[0.078]$} \\
\hline Trade (\% of GDP) & 0.004 & [0.003] & $0.004^{*}$ & [0.002] \\
\hline Oil rents (\% of GDP) & $0.022^{* *}$ & [0.011] & 0.008 & [0.009] \\
\hline Consumption (\% of GDP) & 0.004 & [0.005] & 0.002 & [0.004] \\
\hline Corruption & $0.157^{* * *}$ & {$[0.054]$} & $0.107^{* *}$ & [0.043] \\
\hline Constant & -0.588 & [1.442] & $-2.744^{* *}$ & [1.162] \\
\hline \multicolumn{5}{|l|}{ [Equation 2] } \\
\hline LDV: FDI $_{t-1}$ & $0.231^{* * *}$ & [0.029] & $0.216^{* * *}$ & [0.029] \\
\hline Government Stability & $0.161^{* * *}$ & [0.028] & & \\
\hline Investment profile & & & $0.187^{* * *}$ & [0.034] \\
\hline $\ln (\mathrm{ENPP})$ & $0.575^{* * *}$ & [0.161] & $0.473^{* * *}$ & [0.161] \\
\hline Consumption (\% of GDP) & -0.021 & {$[0.016]$} & -0.015 & {$[0.016]$} \\
\hline $\ln ($ GDP per capita) & $0.055^{* * *}$ & [0.017] & $0.050^{* * *}$ & {$[0.017]$} \\
\hline Trade (\% of GDP) & $0.988^{* * *}$ & [0.144] & $0.910^{* * *}$ & [0.151] \\
\hline Oil rents (\% of GDP) & $0.013^{* * *}$ & [0.004] & $0.013^{* * *}$ & [0.004] \\
\hline Corruption & 0.003 & [0.008] & 0.007 & [0.008] \\
\hline Constant & $-6.208^{* * *}$ & [2.136] & $-6.075^{* * *}$ & [2.152] \\
\hline Indirect Effect & $0.049^{* *}$ & [0.022] & $0.044^{* *}$ & [0.022] \\
\hline Total Effect & $0.520^{* * *}$ & [0.161] & $0.427^{* * *}$ & [0.159] \\
\hline$\%$ mediated & $9.42 \%$ & & $10.30 \%$ & \\
\hline Fixed Effects & yes & & yes & \\
\hline Observations & 1058 & & 1058 & \\
\hline$R^{2}$ & 0.745 & & 0.845 & \\
\hline
\end{tabular}

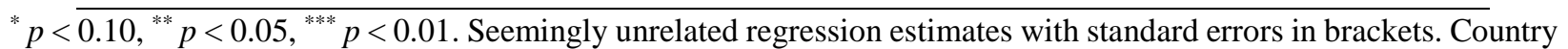
fixed effects are applied but the result is abbreviated to save space. 
This is an author-produced, peer-reviewed version of this article. The final, definitive version of this document can be found online at Political Studies, published by SAGE. Copyright restrictions may apply. doi: 10.1177/0032321718799015

Table 4. Sensitivity Analysis

\begin{tabular}{|c|c|c|c|c|c|}
\hline & $\begin{array}{c}(1) \\
\text { FDI (WDI) }\end{array}$ & $\begin{array}{c}\text { (2) } \\
\text { LDV }\end{array}$ & $\begin{array}{c}\text { (3) } \\
\text { FDI/GDP (\%) }\end{array}$ & $\begin{array}{c}(4) \\
\text { polity } \geq 9\end{array}$ & $\begin{array}{c}(5) \\
\text { polity<9 }\end{array}$ \\
\hline \multirow[t]{2}{*}{$\ln (\mathrm{ENPP})$} & $0.269^{* *}$ & $0.430^{* * *}$ & $0.891^{*}$ & $1.394^{* * *}$ & $0.591^{* *}$ \\
\hline & {$[0.11]$} & [0.16] & {$[0.46]$} & [0.52] & {$[0.29]$} \\
\hline \multirow[t]{2}{*}{ Polity2 } & -0.006 & $0.035^{* *}$ & 0.079 & {$[0.37]$} & 0.024 \\
\hline & {$[0.01]$} & {$[0.02]$} & {$[0.05]$} & 0.783 & {$[0.02]$} \\
\hline \multirow[t]{2}{*}{ ln(GDP per capita) } & $1.083^{* * *}$ & $0.847^{* * *}$ & 0.477 & 0.006 & $0.538^{*}$ \\
\hline & {$[0.14]$} & [0.14] & {$[0.52]$} & {$[0.01]$} & {$[0.29]$} \\
\hline \multirow[t]{2}{*}{ Trade (\% of GDP) } & $0.012^{* * *}$ & $0.007^{*}$ & 0.010 & {$[0.12]$} & 0.01 \\
\hline & {$[0.00]$} & {$[0.00]$} & {$[0.01]$} & 0.006 & {$[0.01]$} \\
\hline \multirow[t]{2}{*}{ Oil Rents } & -0.012 & $-0.036^{* *}$ & $0.099^{*}$ & 0.245 & $-0.05^{* *}$ \\
\hline & {$[0.01]$} & [0.02] & {$[0.06]$} & {$[0.18]$} & {$[0.03]$} \\
\hline \multirow[t]{2}{*}{ Consumption } & 0.002 & 0.003 & $0.046^{*}$ & 0.005 & 0.000 \\
\hline & {$[0.00]$} & {$[0.01]$} & {$[0.03]$} & {$[0.02]$} & {$[0.010]$} \\
\hline \multirow[t]{2}{*}{ Corruption } & 0.095 & 0.117 & 0.275 & 0.245 & $0.452^{* * *}$ \\
\hline & [0.06] & [0.08] & [0.19] & [0.17] & [0.14] \\
\hline \multirow[t]{2}{*}{$\ln$ (population) } & $5.170^{* * *}$ & $3.935^{* * *}$ & $8.920^{* * *}$ & $10.663^{* * *}$ & $7.209^{* * *}$ \\
\hline & [0.49] & [0.53] & [1.89] & [3.10] & [1.03] \\
\hline \multirow[t]{2}{*}{$\mathrm{FDI}_{\mathrm{t}-1}$} & & $0.20^{* * *}$ & & & \\
\hline & & {$[0.03]$} & & & \\
\hline \multirow[t]{2}{*}{ Constant } & $-66.11^{* * *}$ & $-67.69^{* * *}$ & $-139.476^{* * *}$ & $-155.928^{* * *}$ & $-109.133^{* * *}$ \\
\hline & [6.43] & [8.20] & [26.28] & [42.88] & [14.22] \\
\hline Fixed Effects & Yes & No & Yes & Yes & Yes \\
\hline Observations & 1059 & 1111 & 1110 & 269 & 844 \\
\hline$R^{2}$ & 0.981 & 0.366 & 0.579 & 0.800 & 0.668 \\
\hline
\end{tabular}

${ }^{*} p<0.10,{ }^{* *} p<0.05,{ }^{* * *} p<0.01$. OLS estimates with panel-corrected standard errors in brackets. Country fixed effects are applied but the result is abbreviated to save space. Panel-specific first-order autoregressive disturbances are applied. 
This is an author-produced, peer-reviewed version of this article. The final, definitive version of this document can be found online at Political Studies, published by SAGE. Copyright restrictions may apply. doi: 10.1177/0032321718799015

\section{Table 5. Random Effect}

\begin{tabular}{|c|c|c|}
\hline & Coefficient & $\mathrm{SE}$ \\
\hline \multicolumn{3}{|l|}{ Within Effects } \\
\hline $\ln (\mathrm{ENPP})$ & $0.709^{* * *}$ & {$[0.246]$} \\
\hline Polity2 & $0.046^{*}$ & [0.025] \\
\hline $\ln$ (GDP per capita) & $0.944^{* * *}$ & [0.262] \\
\hline Trade/GDP (\%) & $0.013^{* *}$ & {$[0.006]$} \\
\hline Oil Rent & $-0.042^{*}$ & {$[0.025]$} \\
\hline Consumption & -0.004 & [0.009] \\
\hline Corruption & $0.304^{* *}$ & [0.127] \\
\hline $\log$ (Population) & $4.803^{* * *}$ & [0.968] \\
\hline \multicolumn{3}{|l|}{ Between Effects } \\
\hline $\ln (\mathrm{ENPP})$ & $-0.548(p=0.110)$ & [0.343] \\
\hline Polity2 & -0.018 & {$[0.057]$} \\
\hline $\ln ($ GDP per capita) & $1.446^{* * *}$ & [0.247] \\
\hline Trade/GDP (\%) & $0.013^{* *}$ & {$[0.006]$} \\
\hline Oil Rent & -0.012 & {$[0.020]$} \\
\hline Consumption & 0.022 & [0.029] \\
\hline Corruption & $0.370^{*}$ & [0.222] \\
\hline $\log$ (Population) & $1.057^{* * *}$ & [0.187] \\
\hline Constant & $-26.269^{* * *}$ & [6.487] \\
\hline Observations & 1113 & \\
\hline$R^{2}$ & 0.498 & \\
\hline
\end{tabular}

${ }^{*} p<0.10,{ }^{* *} p<0.05,{ }^{* * *} p<0.01$. OLS estimates with panel-corrected standard errors in brackets. Panel-specific first-order autoregressive disturbances are applied. Panel-specific first-order autoregressive disturbances are applied. 
This is an author-produced, peer-reviewed version of this article. The final, definitive version of this document can be found online at Political Studies, published by SAGE. Copyright restrictions may apply. doi: 10.1177/0032321718799015

Table 6. Additional Control Variables

\begin{tabular}{|c|c|c|c|c|c|}
\hline & (1) & (2) & (3) & (4) & (5) \\
\hline \multirow[t]{2}{*}{$\ln (\mathrm{ENPP})$} & $0.632^{* * *}$ & $0.754^{* *}$ & $0.799^{* * *}$ & $0.713^{* * *}$ & $0.815^{* * *}$ \\
\hline & {$[0.234]$} & {$[0.314]$} & {$[0.245]$} & {$[0.243]$} & {$[0.272]$} \\
\hline \multirow{2}{*}{ Polity2 } & $0.061^{* * *}$ & 0.017 & $0.056^{* *}$ & 0.039 & 0.001 \\
\hline & [0.024] & {$[0.036]$} & {$[0.023]$} & {$[0.024]$} & [0.023] \\
\hline \multirow[t]{2}{*}{ ln(GDP per capita) } & $0.868^{* * *}$ & $1.376^{* * *}$ & $0.834^{* * *}$ & 0.347 & -0.067 \\
\hline & {$[0.238]$} & {$[0.233]$} & {$[0.234]$} & {$[0.311]$} & {$[0.295]$} \\
\hline \multirow[t]{2}{*}{ Trade (\% of GDP) } & 0.005 & 0.008 & 0.007 & 0.004 & 0.003 \\
\hline & [0.006] & {$[0.006]$} & {$[0.006]$} & {$[0.006]$} & {$[0.006]$} \\
\hline \multirow[t]{2}{*}{ Oil Rents } & $-0.060^{* *}$ & -0.022 & $-0.053^{* *}$ & $-0.055^{* *}$ & -0.039 \\
\hline & {$[0.024]$} & {$[0.026]$} & {$[0.023]$} & {$[0.025]$} & {$[0.029]$} \\
\hline \multirow[t]{2}{*}{ Consumption } & 0.008 & 0.006 & 0.006 & 0.001 & 0.003 \\
\hline & [0.009] & {$[0.010]$} & [0.009] & [0.009] & [0.009] \\
\hline \multirow[t]{2}{*}{ Corruption } & $0.382^{* * *}$ & $0.220^{*}$ & $0.392^{* * *}$ & $0.426^{* * *}$ & $0.381^{* * *}$ \\
\hline & {$[0.118]$} & [0.133] & {$[0.121]$} & {$[0.124]$} & [0.095] \\
\hline \multirow[t]{2}{*}{$\ln ($ population) } & $6.254^{* * *}$ & $4.006^{* * *}$ & $6.348^{* * *}$ & $3.165^{* *}$ & $17.649^{* * *}$ \\
\hline & {$[0.883]$} & {$[0.908]$} & {$[0.864]$} & {$[1.270]$} & [4.656] \\
\hline \multirow[t]{2}{*}{ Presidentialism } & $0.997^{* *}$ & & & & \\
\hline & {$[0.445]$} & & & & \\
\hline \multirow[t]{2}{*}{ Left-Right } & & 0.020 & & & \\
\hline & & {$[0.097]$} & & & \\
\hline \multirow[t]{2}{*}{ Judicial Independence } & & & -0.016 & & \\
\hline & & & {$[0.200]$} & & \\
\hline \multirow[t]{2}{*}{ year } & & & & $-0.142^{* * *}$ & \\
\hline & & & & [0.023] & \\
\hline \multirow[t]{2}{*}{ year $^{2}$} & & & & $0.000^{* * *}$ & \\
\hline & & & & {$[0.000]$} & \\
\hline \multirow[t]{2}{*}{ Constant } & $-97.329^{* * *}$ & $-66.879^{* * *}$ & $-98.571^{* * *}$ & 0.000 & \\
\hline & [12.242] & [12.429] & [12.060] & {$[0.000]$} & \\
\hline Observations & 1111 & 719 & 1103 & 1113 & 1113 \\
\hline$R^{2}$ & 0.648 & 0.635 & 0.629 & 0.633 & 0.725 \\
\hline
\end{tabular}

${ }^{*} p<0.10,{ }^{* *} p<0.05,{ }^{* * *} p<0.01$. OLS estimates with panel-corrected standard errors in brackets. Country fixed effects (and panel-specific trends for Model 5) are applied but the result is abbreviated to save space. Panel-specific first-order autoregressive disturbances are applied. 
This is an author-produced, peer-reviewed version of this article. The final, definitive version of this document can be found online at Political Studies, published by SAGE. Copyright restrictions may apply. doi: 10.1177/0032321718799015

Figure 1. Country-Means of Institutions and FDI: OECD vs. Non-OECD Countries
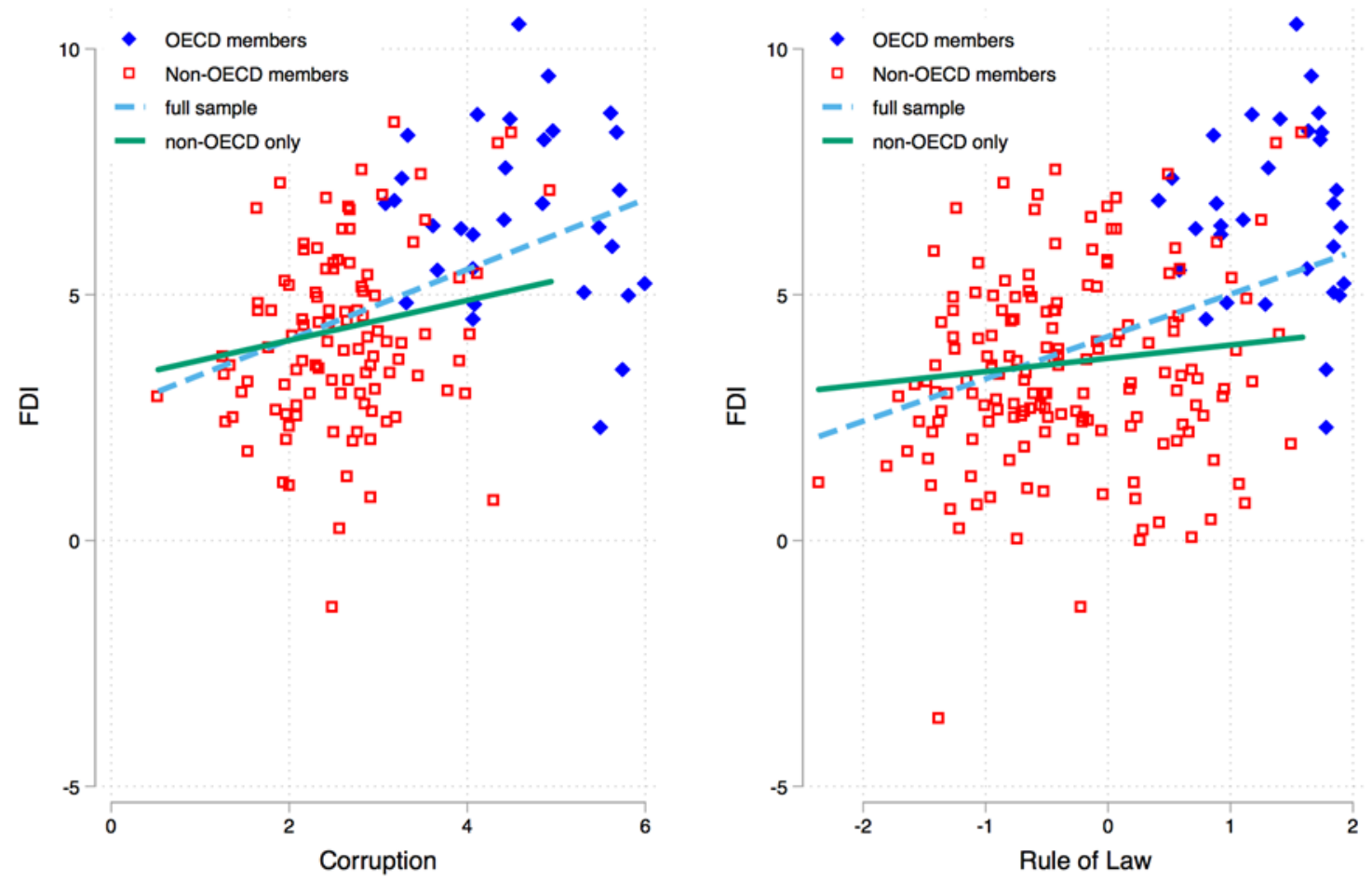

Note: The vertical axis represent natural log of FDI inflow, the details of which are explained below in the research design section. The horizontal axis indicates the level of 'corruption control' (the higher, the less corrupt) on the left panel and 'rule of law' on the right panel using ICRG data. Country-means for each variable are used. 
This is an author-produced, peer-reviewed version of this article. The final, definitive version of this document can be found online at Political Studies, published by SAGE. Copyright restrictions may apply. doi: 10.1177/0032321718799015

Figure 2. Venezuela

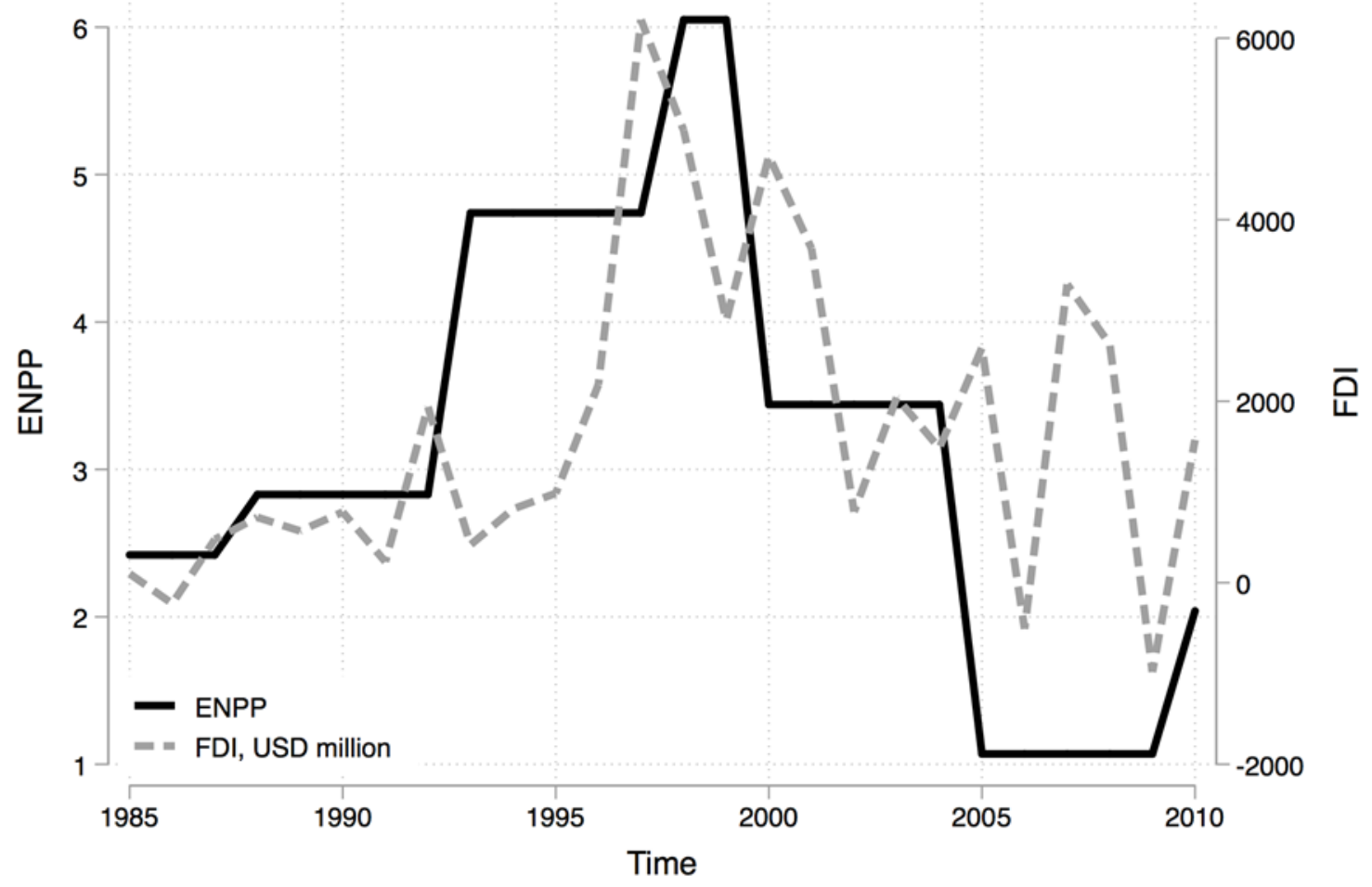

Figure 3. Albania

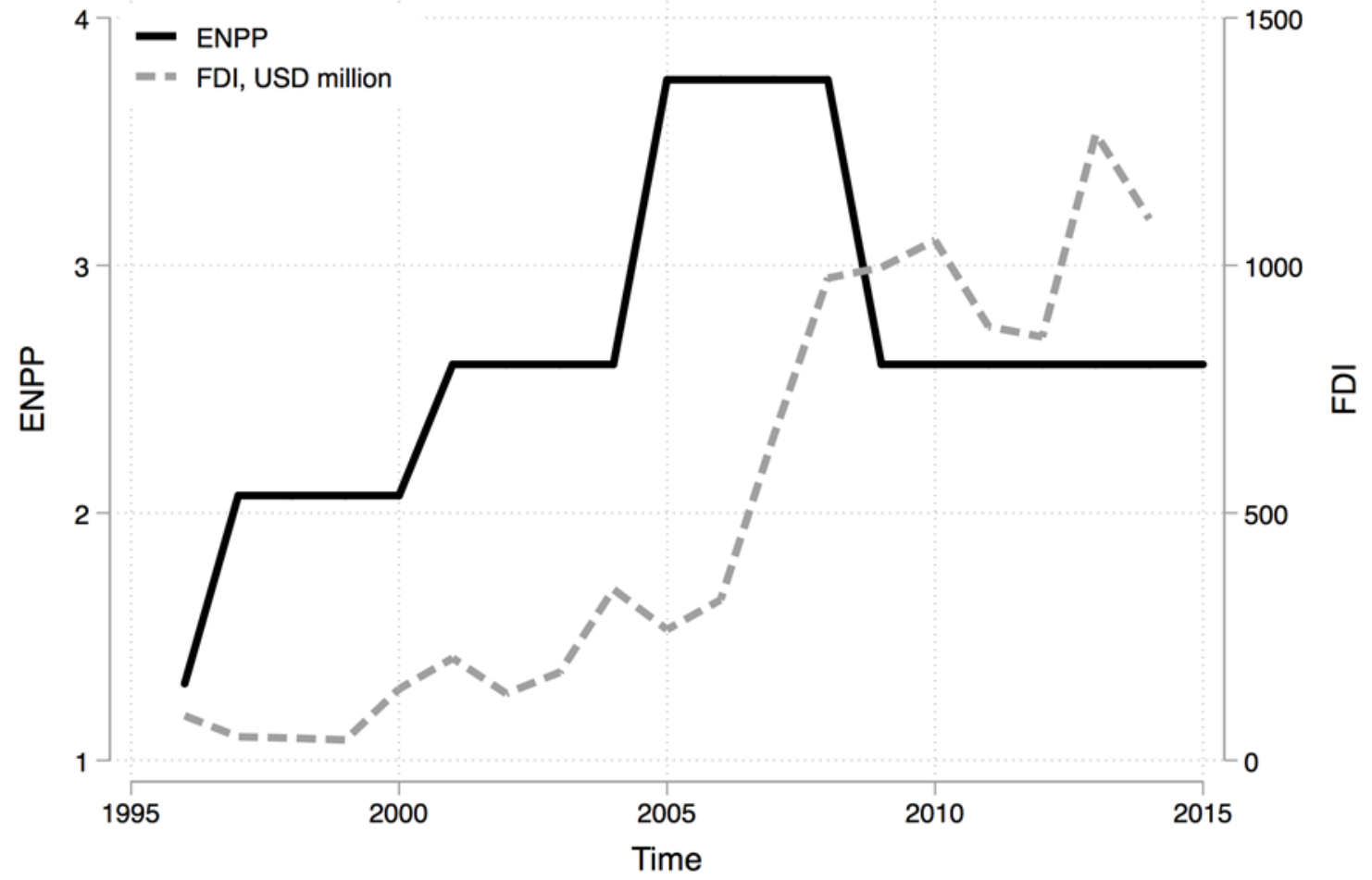


This is an author-produced, peer-reviewed version of this article. The final, definitive version of this document can be found online at Political Studies, published by SAGE. Copyright restrictions may apply. doi: 10.1177/0032321718799015

\section{Figure 4. Marginal Effect of ENPP on FDI with 95\% CI}

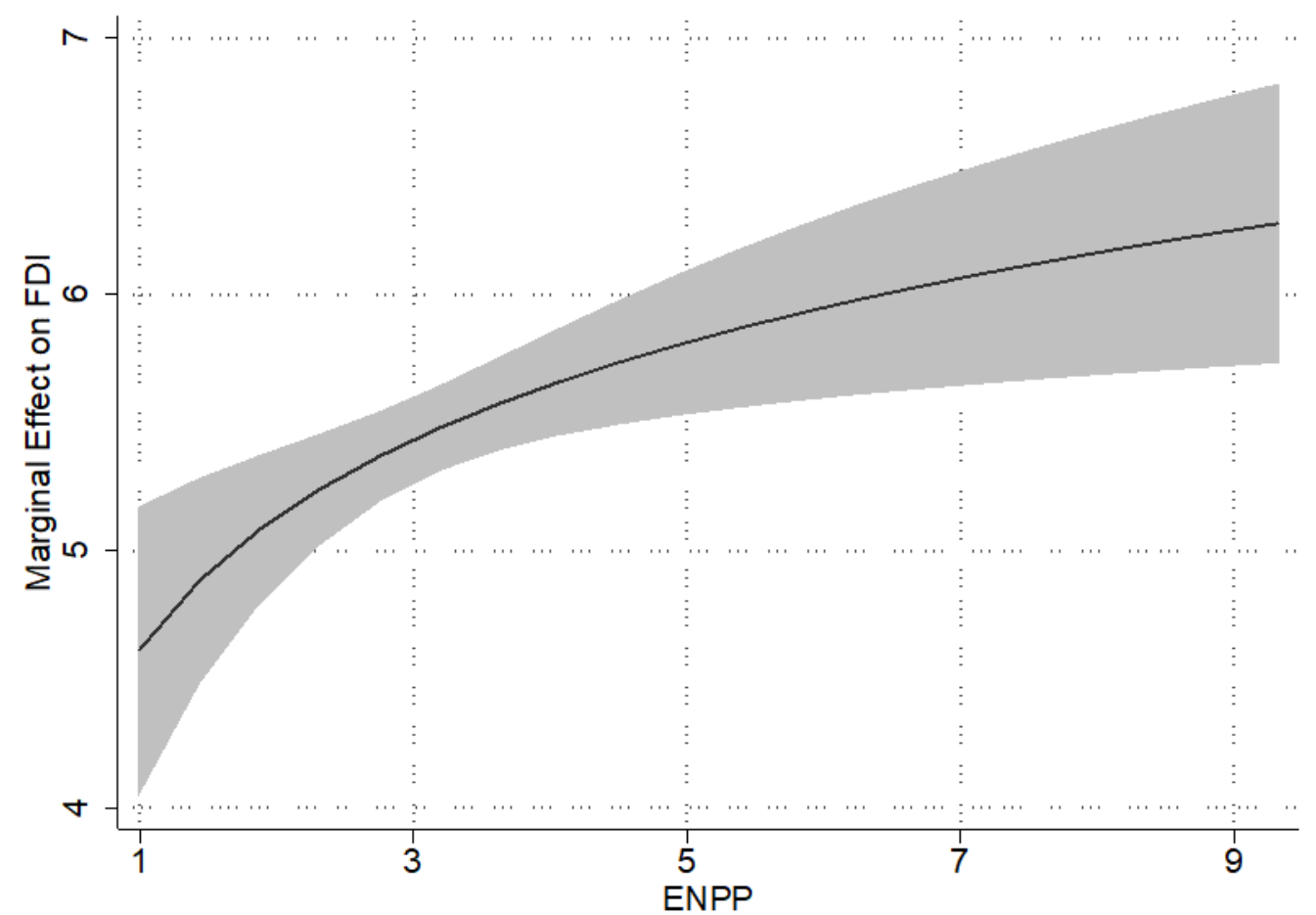

Based on the Benchmark Result. The horizontal axis is adjusted so as to express the effect of $\ln (\mathrm{ENPP})$ on an unlogged scale.

Figure 5: Causal Mediation Analysis

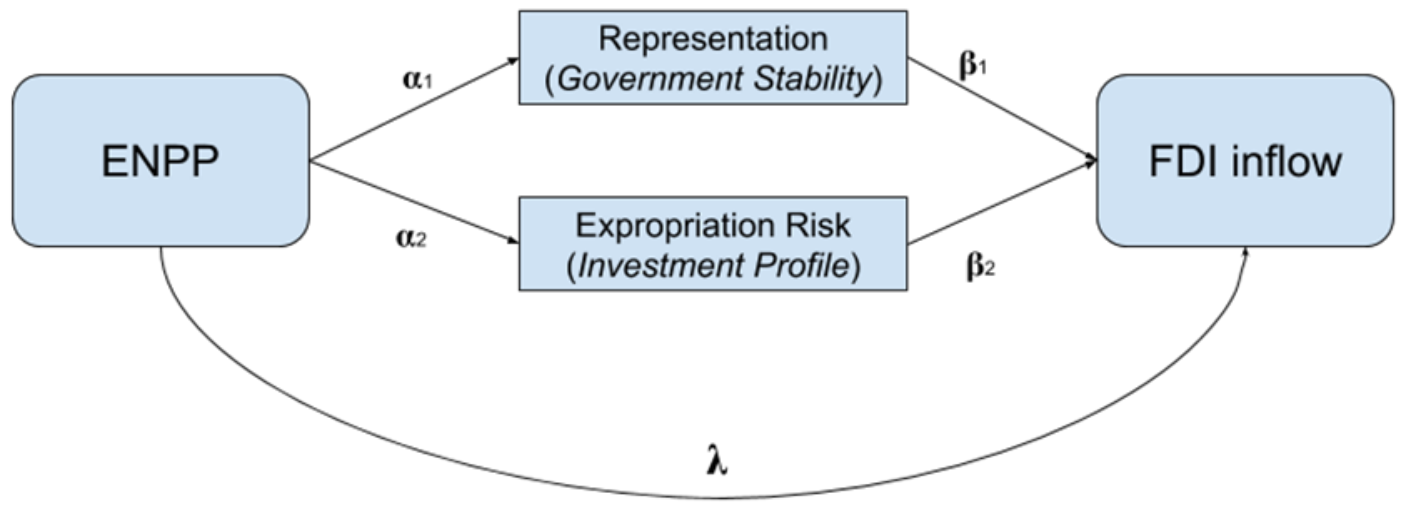


This is an author-produced, peer-reviewed version of this article. The final, definitive version of this document can be found online at Political Studies, published by SAGE. Copyright restrictions may apply. doi: 10.1177/0032321718799015

\footnotetext{
Notes

${ }^{\text {i }}$ Generally speaking, democratic regimes are more representative, accountable, and responsive in nature as compared to non-democratic regimes (Riker, 1965; Dahl, 1973; Schmitter and Karl, 1991).

ii Several studies focus on international determinants of FDI inflows such as Jensen (2004) and Büth and Milner (2008), among others. Since this study, in contrast, focuses on the domestic determinants of investments, the literature review discusses the domestic factors in greater detail.

${ }^{\text {iii }}$ We run the analysis on a sample of developed countries as well and as expected, ENPP does not play a significant role in attracting FDI inflows in this sample. This reaffirms our argument that ENPP is an especially useful indicator of the policy-making environment for potential investors among developing countries. Results available from the authors upon request.

iv One of the most important legislations is the law titled 'On foreign Investment', which was passed in 1993 to encourage foreign investments by giving the same protections to foreign investors and domestic investors (Alexiou and Toro, 2006: 68).

${ }^{v}$ We present below findings using WDI FDI data as well as a robustness check. However, we use UNCTAD data for our benchmark analysis as it provides the most comprehensive data on FDI by reducing the chances of nonreporting of FDI flows by developing countries (Büth and Milner, 2008).

${ }^{\text {vi }}$ ENPP is constructed by using Laakso and Taagepera (1979): ENPP $=1 / \Sigma \mathrm{S}_{\mathrm{i}}{ }^{2}$, where $\mathrm{S}_{\mathrm{i}}$ is the percentage of seats won by the ith party at the legislature. Independent or 'others' are treated as a single party.

vii One can argue that the 'competitiveness of political participation,' one of the indicators of Polity index might also be a source ENPPs. While this is plausible, we view that the relationship between participation and electoral results as an empirical one, which does not necessarily hold. Indeed, dropping Polity index does not alter the benchmark result.

viii For judicial independence we use ‘Judicial Independence’ from Cingranelli and Richards (2010). The original variable is trichotomous and we re-coded the variable into a dichotomous one where 'partially independence' of judicial power is considered not independent. For presidential systems and partisanship of governments, we use the updated version of the DPI data (Beck et al., 2001).
} 